\title{
THE NEW FROM THE OLD
}

\author{
Vitezslav Orel ${ }^{*}$
}

Barvicova 56, 60200 Brno, Czech Republic

Received: March 16, 2009; Accepted: July 27, 2009

The history of science, the arts, and so on, is often as equally instructive as is the science itself. It forces us to compare our contemporary knowledge with the preceding one and, since in all comparisons one must think more than in a mere one-sided observation, the history of science thus forces us to think more than the science alone reveals.

The quoted text is the first sentence of the short essay by J. K. Nestler (1783-1841), published in Brno in 1831 with the title "The new from the old". After finishing his studies in agriculture at Vienna University, Nestler cooperated with C. C. André (1763-1831) in Brno in editing the journal "Oekonomische Neuigkeiten und Verhandlungen", dedicated to the development of science as it applied to agriculture and industry. The 6,000 copies of the journal were distributed to German-speaking people in different European countries. While attending the enthusiastic discussions by members of the Sheep Breeders' Society (SBS), established by André in Brno in 1814 for the improvement of sheep breeding for wool production to benefit the textile industry, Nestler became acquainted with the endeavor to elaborate scientific breeding. In 1823, having been named professor of agriculture and natural history at Olomouc University in Moravia, he paid great attention to the improvement of breeding methods in the context of the growth of knowledge in the natural sciences. In 1829 he published a portion of his lectures titled, "The Influence of generation on the characteristics of progeny" 2 . When explaining problems within the text he used the term heredity, which was not accepted as a scientific term by naturalists at that time. Learning from animal breeding in England and in Moravia, he stressed the importance of the growth of knowledge for the improvement of agriculture in general. Thus he encouraged SBS members in 1836-7 to recommend the investigation of "the physiology of heredity" and formulated "the research question of heredity" 3 . Towards the end of 1837 Nestler also published an extensive paper titled, "Heredity in sheep breeding" 4 . In this context he briefly mentioned the changes of species that occur in nature and the analogy of imitating the process in creating new animal forms. Learning from breeders' experiences with the problems of inbreeding during the last 50 years, he published his paper "On Inbreeding" in $1839^{5}$. Twenty years later Darwin described the process of natural selection and six years after that Mendel elucidated the origin and development of plant hybrids. Darwin did not use the

* Emeritus Head of the Mendelianum in Brno term evolution nor did Mendel use the term heredity. In his essay Nestler stressed the importance of the collection of specific publications and archives to be used in historical investigation. He wished to contribute himself in his teaching and research, but only to a very limited extent. It is the task of the agriculturists to provide the means for creating such collections to be used for the growth of scientific knowledge. The remarkable suggestion Nestler made is reproduced in the following lines:

Up to now we do not have the history of the agricultural science that would be necessary and instructive. The attempts of Ankon, Rossig, and Thaer are valuable works, but rather one-sided, elaborated only in general or too short, offering little advice for the practical farmer. Similar attempts from my pen, ready for some years in my desk, repeatedly extracted and lectured, also do not satisfy me, even though they are welcomed by my indulgent friends. As profitable for us, as is the history of European agriculture, could be the history of agriculture of the Austrian Empire in all its parts, mostly in our native country and its neighbouring parts as it was connected to the prehistoric economy. It is nearly impossible for an individual to elaborate this special agricultural history because no sole writer did proscribe to supply the history and present time as the development of the history of peace and agriculture of the present and of the past. This field of history is therefore raw and undeveloped. To make it fruitful it is necessary for many collaborators to dig with greatest exertion into the collection of books and archives. There is no suitable historian now for this work, for no one has the necessary previous knowledge and where there is neither an order nor a hope of salary or promise, there is little incentive. Should this gap of man's developmental-history be filled in, than it must be realized by agriculturists themselves. With this I invite my business friends in the Empire and, particularly, those of my native country who will benefit to help in collecting material for the history of our agriculture. Each even a small contribution, when its origin is known, could provide a foundation stone, which could be used among ourselves or by someone coming after us. I myself wish to encourage all who have access to the old handwritten documents and archives to participate in this collection. I myself also wish to help as much as possible in my humble power. Olomouc January 1831.

\section{REFERENCES}

The quoted papers were published in the weekly Mittheilungen der k.k. Mährisch -Schlesischen Gesellschaft zur Beförderung des Ackerbaues, der Natur- und Landeskunde in Brünn, abbreviated as Mittheilungen. 
1. Nestler JK. (1831) Neues aus der alten Zeit, Mittheilungen, pp. 71-2.

2. Nestler JK. (1829) Ueber den Einfluss der Zeugung auf die Eigenschaften der Nachkommen, Mittheilungen, pp. 369-72; 37780; 394-8; 401-4.

3. Bartenstein E, Teindl F, Hirsch J, Lauer C. (1837) Protokol über die Verhandlungen bei der Schafzüchter-Versammlung in 1837, Mittheilungen, pp. 201-5; 225-31; 233-8.

4. Nestler JK. (1837) Ueber Vererbung in der Schafzucht. Mittheilungen, pp. 263-9; 273-9; 281-6; 289-300; 318-320.

5. Nestler JK. (1839) Ueber Innzucht, Mittheilungen, pp. 121-8. 